\title{
Modification of the Interpretative Phenomenological Analysis (IPA) Proposal for the Purposes of Empirical Theology (IPA / ET) ${ }^{1}$ Jan Kaňák, Barbora Racková
}

\begin{abstract}
The article deals with the possibility of using Interpretive Phenomenological Analysis as a basis for the theological-social science framework of the research data analysis in the context of empirical theology. It first points out the possibility of interconnecting the theological and social science worldviews. Then it defines guidelines for such an interconnection. In the last part of the article, a model proposal for the analysis and interpretation of research data is formulated. The text is understood as a possible starting point for a wider discussion on the proposed model.
\end{abstract}

Keywords: empirical theology, IPA, social sciences, theology, conceptualisation, data analysis, data collection, critical correlation

\section{Introduction}

Just as in the helping professions and in the social science worldview, the possibility of integrating spirituality and theology is sought, and there is a search for contact points and intersections with the social science worldview in theology. On the part of theology, this process mainly concerns the sociological study of religious phenomena and the use of social sciences within the triad of see-judge-act, or especially (since the 1990s) within empirical or descriptive theology. ${ }^{2}$ In this context, Heimbrock ${ }^{3}$ points to the ever-increasing number of social science practices and views

1 The creation of the text was financed partly by the grant PROGRES Q01 - Teologie jako zpuัsob interpretace historie, tradice a současné společnosti, and partly by other internal sources of HTF UK.

2 For example, Monika ARDELT and Amy AI, Faith and Well being in Later Life: Linking Theories with Evidence in an Interdisciplinary Inquiry, in: Faith in the Well-being in Later Life: Linking Theories With Evidence in and Interdisciplinary Inquiry, ed. Amy AI and Monika ARDELT, London: NOVA Science Pub Inc., 2009; Pamela ERWIN, Youth Ministry Education: Where Practice, Theology, and Social Science Intersect, The Journal of Youth Ministry 2/2006, pp. 9-17; Leslie FRANCIS and Andrew VILLAGE, Go and Observe the Sower: Seeing Empirical Theology at Work, Journal of Empirical Theology 28/2015, pp. 155-183; Andrew LYNCH, Social Theory, Theology, Secularization and World Youth Day, New Zealand Sociology 2/2008, pp. 34-46; Michal OPATRNÝ, Sociální práce a teologie: Inspirace a podněty sociální práce pro teologii, Praha: Vyšehrad, 2013, pp. 240-251; Jana ŠÍDLOVÁ, Možnosti využití empirických metod v (praktické) teologii, Caritas et Veritas 7/2017, pp. 256-268; Amos YONG, What's Love Got to Do with It? The Sociology of Godly Love and the Renewal of Modern Pentecostalism, Journal of Pentecostal Theology 21/2012, pp. 113-134.

3 Hans-Günter HEIMBROCK, From Data to Theory: Elements of Methodlogy in Empirical Phenomenological Research in Pracitical Theology, International Journal of Practical Theology 2/2005, pp. 273-299. 
that are present in theology. Although in the context of English and German written literature the concept of empirical or descriptive (hereinafter referred to as empirical, or as ET) theology is relatively well represented (there is, for example, the Journal of Empirical Theology), in the Czech Republic theological texts deal with it rather marginally - see below the text by Šídlová and the translation of the article by Oviedo from 1999. ${ }^{4}$

In this article, we try to propose a model that attempts to integrate both worldviews at the level of data analysis and at the level of conceptualisation of research. Then we want to present it for further discussion in the field of theological sciences in our country. ${ }^{5}$ There were several reasons for choosing Interpretative Phenomenological Analysis (IPA) as a starting point for the social sciences. First, we considered the use of a qualitative research framework that is already linked to empirical theology. ${ }^{6}$ Within the considerations of empirical theology about qualitative research, there are theses about the application of phenomenology as a certain general way of relating to the world. ${ }^{7}$ It also seems that IPA and theological hermeneutics (at least at the level of event hermeneutics) has a common feature. The interpreter/researcher is part of the interpretation itself. Thus, he cannot deviate from it, or cannot stay out of it (about IPA, see chapter 2.2 below). ${ }^{8}$ It is also necessary to mention that phenomenology is already present in some way in the context of theology. This is true not only for 'those whose research leads them into the practical realm of dealing with people', but also for 'those who work with texts and artifacts.' It evokes or might evoke an internal tension between the truth understood as manifesting (in the context of 'religious revelation') and the truth that is recognised as functioning (this is how it works in the world according to empiricism). ${ }^{10}$ Although we will address this tension below, we believe that it must be said in advance that we think of this tension primarily as the result of different ways of narrating the world. These may meet each other in the form of interpretive relativism. ${ }^{11}$

\section{Current State of Knowledge}

It can be simply said that professional texts and approaches that connect the theological perspective with both a quantitative (in the sense of descriptive theology or ecclesiological statistics) and qualitative social science framework appear in the context of empirical theology. In recent years, the possibility of linking ET and action research has been discussed. The recognised integral part of the action research, in addition to acquiring a certain type of knowledge, is also the balance

4 Lluis OVIEDO, K empirické teologii: možnosti a metody, Teologické texty 3/1999, pp. 81-86.

5 Contrary to our usual approach, we do not rely on the formulation of the question answered in the text (whether it is a basic research question or a question on a review article). It is mainly because the output should not be the answer to the question but the proposed model presented for further critical verification. Thus, we do not respond to the challenges of interconnecting and connections concerning theological discourses and discourses of the social sciences in the sense of 'this is it'. It is rather an offer and a challenge for further discussion and searching and verifying the usefulness of the presented framework for dealing with empirical data in the context of theology.

6 Noel WOODBRIDGE, The EDNA Model for Doing Research in Practical Theology: A Biblical Approach, Conspectus 17/2014, pp. 89-121.

7 Cf. HEIMBROCK, From Data..., p. 276.

8 Petr GALLUS, Teologie a hermeneutika: několik kritických poznámek k hermeneutické teologii, Testimonia Theologica 2/2017, pp. $26-52$.

9 Robyn HORNER, Towards a Hermeneutic-Phenomenological Methodology for Theology, International Journal of Practical Theology 2/2018, pp. 153-173.

10 Colby DICKINSON, Theology and Contemporary Contitnetal Philosophy, London: Rowman \& Littlefiled, 2019, p. 114.

11 Sandra HEINEN and Roy SOMMER, Introduction: Narratology and Interdisciplinarity, in: Narratology in the Age of Cross-Disciplinary Narrative Research, ed. Sandra HEINEN and Roy SOMMER, London: de Gruyter, 2009, pp. 1-10; Bo PETTERSSON, Narratology and Hermeneutics: Forging the Missing Link, in: Narratology in the Age of Cross-Disciplinary Narrative Research, ed. Sandra HEINEN and Roy SOMMER, London: de Gruyter, 2009, pp. 11-34. 
of the necessary change and its subsequent implementation. There are also obvious efforts to apply narrative approaches or ethnography to ET. ${ }^{12}$ We believe (also with regard to the connection between phenomenology and theological hermeneutics) that it is possible and appropriate to supplement these specific methods with an offer to use IPA in the context of ET. Before this step, it is necessary to briefly address the dialogue of social sciences and theology on a more general level.

\subsection{Forms of Dialogue (Disciplinarity) of Theology and Social Sciences}

In the Czech language context, Šídlová devotes herself to this relationship or dialogue. We will briefly mention her division and use it for a closer look at the tension mentioned by Dickinson. ${ }^{13}$ This tension concerns 'truth granted only at the hands of the divine' and 'phenomena directly observable in our world. ${ }^{14}$ Šídlová (following non-Czech sources) distinguishes between monodisciplinarity (application of only one initial view), multidisciplinarity (theology taking over and then interpreting the outputs of social sciences), interdisciplinarity (the cooperation of both with the preservation of the subject specificity of each view), and intradisciplinarity (which is characteristic by the tendency to cross the boundaries of individual cooperating disciplines in the sense of inspiration of one discipline for another).$^{15}$ In recent years, the definition of a relationship (or multi-disciplinary dialogue) called transdisciplinarity has also been developed. Its proponents argue mainly that we live in a super-complex world in which a monodisciplinary view is not always useful. If the findings and conclusions formulated by both the social sciences and theology are usable for the 'real-world challenges', then their interconnection may provide a broader and more applicable view than monodisciplinary or multidisciplinary approaches. Dialogue between individual scientific disciplines is then understood by transdisciplinarity as mutual learning and the creation of something new. ${ }^{16}$

From the point of view of that dialogue between the social science and theological perspectives, it is therefore possible to speak of a gradual approach and subsequent blending on the way from monodisciplinarity to transdisciplinarity. In this text, our base is a transdisciplinary approach, that is, the possible intertwining of both worldviews or narratives about the world. However, this concept logically raises the question of how to understand that dialogue in terms of the tension (if we paraphrase Dickinson) between revealed and measured truth? For those concepts that accentuate one initial discipline (area), the answer seems relatively clear: the ultimate truth is the discipline that is the initial one. This one integrates elements which fit into its narration. But how can we answer if there is a transdisciplinary view?

\subsection{Transdisciplinarity and Critical Correlation}

Within the theological framework, it would be possible to start looking for an answer to such a question in the context of the theses by Tillich, Küng, Schillebeeckx, Tracy, etc. Those talk about critical correlation, critical confrontation or mutual critical correlation and conversation. The

12 Eileen CAMPBELL-REED and Christian SCHAREN, Ethnography on Holy Ground: How Qualitative Interviewing is Practical Theological Work, International Journal of Practical Theology 2/2013, pp. 232-259; Elaine GRAHAM, Is practical theology a form of action research, International Journal Practical Theology 1/2013, pp. 148-178; cf. HEINEN and SOMMER, Introduction..., pp. 1-10.

13 At this point, we would like to thank both reviewers for pointing out the absence of this aspect in the first version of the presented text.

14 Cf. DICKINSON, Theology..., p. 9.

15 Cf. ŠíDLOVÁ, Možnosti..., pp. 258-263.

16 Alex BAUMBER et al., Learning together: a transdisciplinary approach to student-staff partnerships in higher education, Higher Education Research and Development, 3/2020, pp. 395-410, p. 396; George LUNDSKOW, The Sociology of Religion: A Substantive and Transcdisciplinary Approach, LA: PN Press, 2008, pp. xi-xiv. 
principles, referred to in theology as the method of correlation, have been present in the theological concept since the 19th century. Although their conception is relatively broad in terms of the specific determination of poles and the meaning of correlation, the common element is the emphasis on the relationship between two sources. One of those sources is anchored in revelation, or the living Jesus, and the second pole is anchored in empiricism, respectively in 'our contemporary existential situation. ${ }^{17}$

If transdisciplinarity is the initial view for this relationship of both poles in theology, then the validity of those poles should have the same importance. This can lead both to finding unity in the outputs of such a dialogue and to a possible confrontation between incompatible outputs and views. However, in both extreme possibilities, the transdisciplinarity is allowed thanks to a common interest in 'respective searches for explanations of the social world and its disorders. ${ }^{18}$ To some extent, this view follows Wilhelm Dilthey's claim (paraphrased in the following quotation) from the 1930s. It says that 'the human soul (or spirit) is a central phenomenon to which all social and cultural sciences apply. ${ }^{\prime 19}$ Following Tracy and his conception of critical correlation, the use of empiricism in theology is a way to reinterpret Christianity and reinterpret postmodernity in its atheistic form even with regard to the acceptance of 'autonomous secularity. ${ }^{20}$ In essence, this approach criticises both the purely dogmatic approach on the part of theology and the purely exclusivist conception of the possibility of knowing the truth on the part of science. The tendency to 'listening events' contains both an empirical and a theological element. ${ }^{21}$

All of these statements and concepts lead to the acceptance of tension and confrontation, and, at the same time, to a critical and reflected acknowledgment of the basic starting points of world research.

If both initial assumptions are equally true, it is necessary to take into account that the new output (which will accept and transcend the original disciplines within the framework of transdisciplinarity) will rather be a description of a certain dynamics between different interpretations - that is, between the revealed and measured truth (description of states in interactions) - than the conclusion in the sense of 'this is it' (description of the state). According to our assumption, this is the only possible outcome in the situation of diametrically different interpretations of the studied phenomenon by theology and social sciences if respect for both frameworks is to be maintained at the same time. As Širka writes, it is not possible to achieve certainty but one has to try to understand. This approach can be useful to theology in accordance with the level of its identification with the assumption that it is as such a public discourse. This means that it belongs to the public space and to everyday life and that it can (even through events understood as signs of the times) use such a position. In his conception for theologians and theology, Tracy postulates this as a necessary condition. ${ }^{22}$

17 Nathan DICKMAN, Anxiety and the Face of the Other, SOPHIA 48/2009, pp. 267-279, p. 268; John SWINTON and Harriet MOWAT, Practical Theology and Qualitative Research, London: SCM Press, 2006, pp. 68-96.

18 Cf. DICKMAN, Anxiety...; Andrew LYNCH, Social Theory, Theology, Secularization and World Youth Day, New Zealand Sociology 2/2008, pp. 34-46, p.35; Gaspar MARTINEZ, Confronting the Mystery of God, New York: Continuum, 2001.

19 Amy AI and Monika ARDELT, Scientific Investigation of the Multifaceted Faith Effects in Aging: A Theory-Based Interdisiplinary Inquiry, in: Faith in the Well-being in Later Life: Linking Theories With Evidence in and Interdisciplinary Inquiry, ed. Amy AI and Monika ARDELT, London: NOVA Science Pub Inc., 2009, pp. ix-xii, p. ix.

20 MARTINEZ, Confronting..., p. 185

21 Nathan DICKMAN, Call or Question: a Rehabilitation of Conscience as Dialogical, SOPHIA 57/2018, pp. 275-294, p. 279.

22 Cf. DICKAM, Anxiety...; MARTINEZ, Confronting...; OPATRNÝ, Sociální...; Zdenko ŠIRKA, Hermeneutika Davida Tracyho, Studia Theologica 2/2019, pp. 154-175; Jakub URBANIAK, Christ-event in Tracy and Badiou, The Heythrop Journal 56/2015, pp. 988-1009. 


\subsection{Guidelines for Examining Empiricism in the Context of ET}

Based on the above theses and authors, as well as on the claims about the connection of ET and the social sciences given by the authors below, we have formulated general recommendations that need to be adhered to or reflected upon when considering the IPA modification applicable to ET. We also offer them here because they can serve as a starting point for expanding the transdisciplinary ${ }^{23}$ approach in terms of the methodology used when studying lived phenomena. These more general recommendations could be divided into three areas: a) topic selection, b) conceptual research / work settings, and c) data collection, analysis, and interpretation. For clarity, we will present the individual recommendations using the paragraphs for each of the mentioned areas.

\section{A) TOPIC SELECTION}

- If we want to remain at the level of practical theology, and do not enter the other border areas of theology (charitable activities, etc.), then 'theological induction' should be present at the beginning of the research, and research as such should address 'theological problems,, ${ }^{24}$ or 'spiritual and theological frame. ${ }^{25}$

- This generally means researching and devoting oneself to 'living religion.26 Jasper describes this process or focus as focusing on the 'embedded meanings of Christian practice.27 Heimbrock talks about exploring the 'living religion. ${ }^{28}$

- One can focus on the 'heart of wise practice rather than universal moral principles. ${ }^{29}$

\section{B) CONCEPTUAL FRAMEWORK}

- The relationship between theology (Scriptures, traditions, etc.) and lived experience (social science data) should have the character of 'mutual criticism' and not a linear criticism of Scripture towards experience. ${ }^{30}$ For example, Majerus and Sandage ${ }^{31}$ thus define the term Differential of Self (DoS) first from a psychological, cultural anthropological, and then subsequently from a theological, respectively biblical conceptual framework.

- In researching, it is necessary to start from the the point that all of our base concepts which influence the concept of reality 'must be owned and acknowledged'. However, this also means that within the reflexivity of the researched topic and data, theology has the same position as social science concepts (psychology, social work, sociology, pedagogy, etc.). ${ }^{32}$ Neither theology nor the social science worldview should dominate 'useful or communicative activities ${ }^{33}$ in the research process.

23 We leave aside approaches and models that are not suitable for a transdisciplinary approach. For example, the model proposed by Switon and Moeat. This one gives the word to the social sciences first (which determine the focus of the topic and the implementation of research), and only then to theology (which performs the critical evaluation of Scripture).

Roger JASPER, Hans-Georg Gadamer and the Mind of Christ, Journal of European Baptist Studies 1/2019, pp. 111-125, p. 112.

HEIMBROCK, From Data..., p. 287.

9 CAMPBELL-REED and SCHAREN, Ethnography..., p. 240.

30 JASPER, Hans-Georg Gadamer..., p. 113.

31 Brian MAJERU and Steven SANDAG, Differentiation of Self and Christian Spiritual Maturity: Social Science nad Theological Integration, Journal of Psychology nad Theology 1/2010, pp. 41-51.

32 JASPER, Hans-Georg Gadamer..., p. 116.

33 HEIMBROCK, From Data to Theory..., p. 289. 
- Man is not seen primarily as an object that needs to be read and is individualised, but as an individual involved in the network of others. At the same time, however, it follows that there is a tendency in the texts to focus on 'stories of lives' in the texts. ${ }^{34}$

\section{C) DATA COLLECTION, ANALYSIS AND INTERPRETATION}

- For data collection/creation, it is necessary to create a 'psychologically, emotionally and spiritually safe open' space in which it will be possible to 'share complex realities of life'.

- It is necessary to use a 'descriptive moment. This position carries the thesis of examining the situation in its 'rich complexity'.

- In this research, it is necessary to focus on 'embodied, relational and contextual sources and norms'. This also includes a focus on 'power and difference in the context of lived experience. ${ }^{35}$

- One needs to be aware of 'the differences between explicit and actualized experiences of religious elements in people's every day life on the one side, and the hidden presence' on the other. ${ }^{36}$

- The emphasis of the analysis should be on 'understanding and interpretation, rather than explanatory or generalizable theory. ${ }^{37}$

- In the case of the implementation of focus-groups, the number of their members reaches approximately seven people. This assures the creation of a secure space for sharing.

- In appropriate situations, common (silent) prayers can also be included in the research process.

To put it simply, it follows from the above that the connection between theology and other scientific disciplines should take place from the very beginning of the research process and from the moment of thinking about the topic and the way of grasping it. The social science view is seen as equally important and pivotal.

\section{Interpretive Phenomenological Analysis}

\subsection{Basic Characteristics of IPA}

IPA, as a qualitative approach in the context of research, was originally formulated by Jonathan Smith during the 1990s, with the aim of creating a tool suitable for exploring personal experiences and grasping identity. ${ }^{38}$ The authors of this method describe its double accent which is visible at the double level of analysis. In the first of them, the researcher tries to describe and decipher individual experiences in the text (or in the process in general). This is empathic hermeneutics. In the second, it is possible to subject the individual experience to further research (questioning hermeneutics). ${ }^{39}$ Taylor then points out three basic characteristics:

34 CAMPBELL-REED and SCHAREN, Ethnography..., p. 243.

35 Ibid., pp. 233-234.

36 HEIMBROCK, From Data..., p. 288.

37 CAMPBELL-REED and SCHAREN, Ethnography..., p. 244.

38 Angela TAYLOR, Using interpretative phenomenological analysis in a mixed methods research design to explore music in the lives of mature age amateur keyboard players, Music Education Research 4/2015, pp. 437-452.

39 Joanna BROCKI and AlisonWEARDEN, A critical evaluation of the use of interpretatitve pheomenological analysis (IPA) in health psychology, Psychology and Health 1/2006, pp. 87-108; Jonathan SMITH and Mike OSBORN, Intepretative Phenomenological Analysis, in: Qualitative psychlogy: a practical guide to research methods, ed. Jonathan SMITH, London: SAGE, 2007, pp. 53-80. 
- IPA is idiographic - data from one communication partner is analysed before further interviews are conducted in order to identify and name similarities and differences. The reason for this approach is the tendency of IPA, in addition to individual interpretations, to offer also a more general description of the perception of a certain phenomenon. For this reason, the sample in IPA usually focuses on a smaller homogeneous group which has good access to the investigated phenomenon. ${ }^{40}$

- IPA is inductive - the starting point is the experience of communication partners with an openness to unusual or unexpected phenomena.

- IPA is interrogative - it refers to previous research. IPA either completes it or sets (formulates) questions for it.

If the central point is experience, it is also possible to consider (in addition to the dimension of experience and knowledge) the view of experience as an experience of contact with God's word or Scripture. ${ }^{41}$ At the same time, however, it is necessary to take into account the fact that phenomenology, as a starting point for IPA, is not a value-neutral setting of research and narration about the world. In this context, Heimbrock draws attention to the possible difficulty of integrating the theological and social science perspectives. This concerns the assumption that events have their consequences and impacts. The application of a causal way of thinking and a model could be problematic mainly because theology (but not only it) does not have to share this simply causal assumption. ${ }^{42}$

\subsection{Recommendations for the Use of IPA as a Tool for Data Collection and Analysis}

Within IPA, certain recommendations are formulated which should be presented here in basic features (with regard to the model proposal described below) even though these recommendations are well elaborated in the professional literature on the IPA. Here we summarise them in points, following the statements of authors such as Koutná Kostínková and Čermák, ${ }^{43}$ Brocki and Wearden, ${ }^{44}$ Smith and Osborn, ${ }^{45}$ Smith, Flowers and Larkin, ${ }^{46}$ Oxley, ${ }^{47}$ Miller, Chan and Farmer, ${ }^{48}$ Restivo, Julian-Reynier and Apostolidis, ${ }^{49} \mathrm{McCoy},{ }^{50}$ and Cassar and Shinebourne. ${ }^{51}$

- In addition to the abovementioned homogeneity of the sample, it should be taken into account that IPA often involves smaller samples ranging from 4 to 10 people. It follows from both that the criteria for selecting a sample (inclusion in a sample) must be relatively

40 Shameena TAMACHI et al., "You understand that whole big situation they're in": intepretative phenomenological analysis of peerassisted learning, BMC Medical Education 18/2018, pp. 1-8.

41 Gregory BAUM, Fernard Dumont: A Sociologist Turns to Theology, London: McGill-Queen's University Press, 2015 , p. 21.

42 HEIMBROCK, From Data..., pp. 293-294.

43 Jana KOUTNÁ KOSTÍNKOVÁ and Ivo ČERMÁK, Interpretativní fenomenologická analýza, in: Kvalitativní analýza textů: čtyři přístupy, ed. Tomáš ŘIHÁČEK, Ivo ČERMÁK and Roman HYTYCH, Brno: MUNI, 2013, pp. 5-42.

44 Cf. BROCKI and WEARDEN, A critical..., pp. 87-108.

45 Cf. SMITH and OSBORN, Interpretative..., pp. 53-80.

46 Jonathan SMITH, Paul FLOWERS and Michael LARKIN, Interpretative Phenomenological Analysis: theory, method and research, London: SAGE, 2012, pp. 9-116.

47 Laura OXLEY, An examination of Interpretation Phenomenological Analysis (IPA), Educational and Child Psychology 3/2016, pp. 55-62.

48 Raissa MILLER, Christian CHAN and Laura FARMER, Interpretative Phenomenological Analysis: A Contemporary Qualitative Approach, Counselor Education and Supervision 57/2018, pp. 240-254.

49 Léa RESTIVO, Claire JULIAN-REYNIER and Thémis APOSTOLIDIS, Pratiquer l'analyse interprétative phénomńologique: intérets et illustration dans le cadre de l'enquete psychosociale par entretiens de recherche. Pratiques Psychologiques 4/2018, pp. 427-449.

50 Lauren MCCOY, Longitudinal qualitative research and interpretative phenomenologickal analysis: philosophical connections and practical considerations, Qualitative Research in Psychology 4/2017, pp. 442-458.

51 Simon CASSAR and Pina SHINEBOURNE, What Does Spirituality Mean To You: An interpretative phenomenological analysis of the experience of spirituality, Existential Analysis 1/2012, pp. 133-148. 
clear, precise, and narrow.

- Within IPA, possible procedures for data analysis are formulated. These, however, always need to be related to specific research situations and orientations. In general, IPA goes from a descriptive to an interpretive focus - from emerging topics to their concretisation and subtopics, to coping. Whether the researcher chooses line-by-line coding, or focuses on emerging topics during repeated readings from the beginning, it depends on the meaning which is sought in the section of the text and the meaning of the analysis itself. In this context, Smith, Flowers and Larkin call on researchers to 'be innovative' while maintaining the premise that it is a 'joint product of a participant and the analyst. ${ }^{52}$

- Research questions are formulated with regard to the focus on personal experience (perception of a certain phenomenon or situation), and, at the same time, on attaching importance to these events and experiences. These should not be questions and topics that are primarily theory-driven, i.e., based on theory. However, reading professional resources and texts can be helpful in the process of focusing on a particular area of human experience.

- Primarily, IPA is not about describing causal relationships and creating models.

- It is recommended for a new or little researched topic and in the situation where it is possible to speak of an atypical researched group - that is, a group which is generally under-represented in the population.

- The recommended way of data creation (we are not specifically talking about data collection here with regard to the generally interactive nature of qualitative research) is semi-structured interviews, however, there are studies which use focus-groups.

- IPA envisages the implementation of operationalisation as a process based on the conceptual definition of terms. At the same time, it still takes into account the focus on individual experience, interpretation, and coping. However, these questions based on theory (from the operationalisation of conceptual definitions) are perceived as secondary or asked only in the second place.

- In addition, IPA uses questions to promote sharing and disclosure, such as 'How do you feel when we talk about this topic?'

- The use of face-to-face interviews is primarily recommended. However, studies using telephone or e-mail contact are known, given the geographical distance or other difficulties that prevent personal interviews.

- Although it is mostly focused on anchoring the phenomenon at a specific time (the temporary context), its use can be found in longitudinal studies as well.

In summary, IPA is a relatively new method of collecting and interpreting data that focuses primarily on the perception and interpretation (including meaning) of a particular experience at the individual level without a tendency to further generalise findings. It seems to be used primarily in situations where the research topic is relatively new or unusual, or when the sample is chosen (with an emphasis on homogeneity) from the population which is something specific, special. The analysis then moves between the individual interpretation of the experience and the interpretation of the researcher. It is impossible to enter the world of communication partners without being affected by this world, and it is impossible to enter into it without any preconditions, to ignore the importance of our understanding for data interpretations.

52 SMITH, FLOWERS and LARKIN, Interpretative..., p. 80. 


\section{Proposal for Modification of IPA - IPA / ET}

In this part of the text, we will first present the input theses which are used in order to define the basic framework of the proposed modification of IPA. This one is essentially the initial perspective of research activities. Subsequently, we will describe the process of conceptualisation, the basic framework of research, data collection and analysis, with regard to theses based on ET and the focus of IPA.

\subsection{Input Thesis of IPA / ET Formulation}

We consider the following to be the basic input for the proposed model (modification of the IPA procedure towards use in ET, hereinafter also referred to as IPA / ET).

- The natural world cannot be 'described in the same way' as the world of science. If we try to describe this natural world of human experience, then this step can be realised by 'focusing on the phenomenal nature (of things), on their revelation..$^{53}$ This revelation is available to all scientific and non-scientific views of the world.

- Theological and social science views of the world (this revelation is described by Patočka) can be perceived as two types of narrations. These two may differ in many ways but, in fact, they deal with the same experience, respectively with the same central phenomenon (see above).

- Both views (theological and social science) should be present in the process from the very beginning.

- For the formulation and selection of the topic, as well as for the subsequent steps in the research, it is necessary to take into account not only the assurance of the focus on theologically related topics (and make them theologically present), but also to use IPA theses on focusing on experience and less researched phenomena as well as on a subsequent way of handling data.

As we have emphasised several times in the text, it is essential for IPA that the topic examined is the perception of a particular type of experience, that is, 'examination of lived experience, ${ }^{54}$ or focusing on 'the lived experience of the participant and the menaning which the participant makes of that lived experience. ${ }^{55}$ At the same time, from the point of view of ET, it is essential that the topic touches on a theological issue or area. The starting point of the research, therefore, from our point of view, is a theologically framed topic (or a topic related to theology), or an area that is new, unexplored, or explored from other perspectives and, in the context of IPA / ET, related to human perception (including the meaning which people give to events and situations). A basic research question is then formulated within that area. An example is an interest in the work of pastoral counselors with young people, more specifically the perception of pastoral counselors' interventions in conflict situations and the question formulated consequently: How do young people perceive the work of pastoral counselors in situations of internal conflict? ${ }^{56}$

3 Jan PATOČKA, Kacírské eseje o filosofii dějin, Praha: Academia, 1990, p. 23.

54 SMITH, FLOWERS and LARKIN, Interpretative..., p. 47.

55 Ibid., p. 80.

56 In order to gain a basic knowledge of IPA, we recommend the freely available chapter of Čermák and Koutná Kostínková in the publication Qualitative Text Analysis: Four Approaches, published by Masaryk University in 2013. As the mentioned publication is freely available, we do not comment on or elaborate some partial parts of the IPA in more detail. 
Therefore, if IPA / ET should focus on the exploration of lived spirituality or religious experience, there is a question to what extent this affects the very second part of the exploration, namely 'the meaning which the participant makes of that lived experience.' Although it is beyond the scope of this text to address the following note in more detail, it should be noted that the term meaning connotes a certain closed (albeit temporarily) correlation to the meaning of a particular event, part of life, or life in general. For some, part of this statement is a kind of internal coherence and integrity - in the sense of a general statement: this makes sense to me. In the theological context, however, this is a problem. Thompson, ${ }^{57}$ but not only him, points out that God and his manifestation on Earth (whether we understand that manifestation as presence, absence of presence, or as specific interventions in human experience and life) is, from a human point of view, inherently paradoxical and cannot be fully understood. We therefore believe that in the context of the modification of IPA towards ET, it is necessary to take into account that participants do not have to find that meaning, or can perceive it as paradoxical, or talk about paradox directly.

\section{Table 1: Basic Overview of the IPA / ET Modification Guidelines}

\begin{tabular}{|c|c|}
\hline Guideline & Specification/Example \\
\hline $\begin{array}{l}\text { A new unexplored topic which is primarily } \\
\text { rooted in theology and concerns the perception } \\
\text { of specific situations - it is expressed by a basic } \\
\text { research question. }\end{array}$ & $\begin{array}{l}\text { How do participants in hagiotherapy groups perceive the } \\
\text { effect of biblical texts in the context of hagiotherapy? } \\
\text { How do long-term hospitalised people perceive in- } \\
\text { terviews with hospital chaplains? }\end{array}$ \\
\hline $\begin{array}{l}\text { One has to focus interviews (during operation- } \\
\text { alisation) on a subjective description of expe- } \\
\text { rience and the meaning of events. It has to be } \\
\text { taken into account that the meaning may also } \\
\text { manifest itself as a paradox. }\end{array}$ & $\begin{array}{l}\text { Following possible recommendations regarding the } \\
\text { structure of the interview, it is possible to focus on } \\
\text { descriptive (description of the explored issues), narrative } \\
\text { (accent of the story around the explored issues), structu- } \\
\text { ral (description of the internal structure of the explo- } \\
\text { red phenomenon), or contrastive (difference between } \\
\text { phenomenon and its opposite) questions.' It would be } \\
\text { appropriate to add questions that focus on the paradox. } \\
\text { There should be questions like, for example, 'Which } \\
\text { experiences (in all that we talk about together) seemingly } \\
\text { or really contradict each other?' Tell me more about the } \\
\text { contradiction. }\end{array}$ \\
\hline $\begin{array}{l}\text { The number of respondents, as well as their oth- } \\
\text { er characteristics, should be chosen according to } \\
\text { IPA recommendations (see above). }\end{array}$ & $\begin{array}{l}\text { The number is not precisely determined: it depends on } \\
\text { the depth of the investigated phenomenon, etc. There are } \\
\text { authors who propose a single-case study }(\mathrm{N}=1) \text {, others } \\
\text { talk about five to seven, some about more participants. }\end{array}$ \\
\hline $\begin{array}{l}\text { One has to actively bring a theological point of } \\
\text { view or insight in relation to spirituality/religion } \\
\text { into the conversations. At the same time, one } \\
\text { has to be open to the fact that this may not play } \\
\text { a role for communication partners experiencing } \\
\text { the phenomenon. }\end{array}$ & $\begin{array}{l}\text { If there is a reference to a theological/spiritual grasp and } \\
\text { topic in the interviews, one has to be prepared to ask } \\
\text { about the position of spirituality/theology in the explo- } \\
\text { red phenomenon. } \\
\text { If it does not appear in the interviews, one should ask } \\
\text { additional questions. This should happen even if this ele- } \\
\text { ment may not be important for communication partners. }\end{array}$ \\
\hline
\end{tabular}

57 George THOMPSON, God is Not Fair, Thank God! Biblical Paradox in the Life and Worship of the Parish, Eugene: Wipf nad Stock Publishers, 2014. 
In the zero phase of the analysis, one has to reflect on not only one's own experience with the topic, but also the influence of spirituality.
One should ask himself questions like 'What knowledge from the field of theology are, specifically for me, related to the researched topic?, 'What is my relationship (in terms of spirituality, religion, or theology) to the topic?', 'What will the others (in my opinion) experience from all this?'

One should be aware of and distinguish the opinions of the communication partners, and how they experience it. Also, one should think about his own thoughts and feelings even from the point of view of theology.

Through similar key concepts, one should observe possible different interpretations of social science exploration of the world and theological exploration of the world.

The logically subsequent step is to create a structure for creating data. The basic option is to use semi-structured interviews. However, in the context of IPA, the use of 'electronic e-mail dialogue, focus-groups, and observation methods have aslo been used for IPA work. ${ }^{58}$ We will remain with semi-structured conversations here. Smith, Flowers and Larkin offer a basic guide for a conversation plan. They move from the 'narrative or descriptive' to the 'analytical or evaluative' part. In both cases, the main actor is a research participant. More specifically, the mentioned authors offer the following possibilities of targeting questions on the explored phenomenon: descriptive (description of the explored phenomenon), narrative (telling about the phenomenon, beginning of the relation to the phenomenon and subsequent development), structural (structure of the explored phenomenon), contrast (description of differences of the phenomenon), evaluative (evaluation of the phenomenon), circular (description of possible views of other people according to the participant), and comparative (evaluation of the phenomenon when taking into account the others). ${ }^{59}$ Among the various possible recommendations for the actual implementation of the interview, let us mention here 'attemption to expose the obvious, ${ }^{60}$ that is, leading the participants towards generally obvious description. It is also appropriate to use a funnelling ${ }^{61}$ strategy which begins with the general and moves to more specific moments of the phenomenon.

So far, the text has shown that the focus of research in the context of IPA is a phenomenon manifested at the level of a) description of the phenomenon and its experience, b) the meaning that is inserted into the experience, and c) possible influence on identity or manifestation of identity in the explored phenomenon. All of it is at the level of the description - evaluation. But what does this mean for IPA / ET and the preservation of part of the theological focus? So far, we know that we provide it by choosing the topic, and by assuming the presence of a paradox in the conversations. However, in order to structure the interview plan, this also means that the spiritual/ religious dimension should be at least present in the prompts. These encourage the participant to focus more deeply on the researched topic. Therefore, if we ask in the prompts, for example, how a certain phenomenon affects our relationships (we ask about family, friends, work, etc.), ${ }^{62}$

\footnotetext{
SMITH, FLOWERS and LARKIN, Interpretative..., p. 57.

Ibid., pp. 59-60.

Ibid., p. 69.

61 SMITH and OSBORN, Interpretative..., p. 62.

62 For more, see SMITH, FLOWERS and LARKIN, Interpretative...., p. 62.
} 
the prompts should also include an invitation to talk about a relationship with God, the church, or his own spirituality, etc.

After the actual implementation of the interview, the usual procedure takes place, namely a literal transcription of the data recorded and created in the interview. For IPA / ET, we recommend keeping, resp. applying what is usual within IPA, that is, implementing the analytical process after the first interview and then after each subsequent one. As with operationalisation (that is, the creation of an interview plan), there is no uniform or precise procedure for analysis within the IPA. We also consider it appropriate for IPA / ET to choose the strategies below (within 'the iterative and inductive cycle'). Smith, Flowers and Larkin offer the following data analysis tools: line-by-line coding; identification of rising or rather emerging patterns; maintaining a dialogue between the researcher, knowledge, codes; creating units or structures; the use of consultations, cooperation, and presentation of reflections and findings (before the next steps), and reflection upon one's own assumptions, and pre-understanding of the researched topic. ${ }^{63}$ The following steps are recommended for the analytical process.

0) Self-reflection, or reflection within dialogue, in which the researcher examines his own pre-understanding of the topic and experience with the topic (this is not without use, one needs to be aware of it). In the context of IPA / ET, in our opinion, the influence of one's own religion/spirituality on data analysis also needs to be reflected upon.

1) Reading and re-reading which serves for a deeper immersion into the perspective of the narrators, i.e., the participants.

2) The first variant of notes and comments.

3) The topics development that grew in the previous step.

4) Finding relationships between these topics.

These five phases or steps of the analysis are realised after the transcription of the first interview. For a more specific description, we refer to the abovementioned chapter by Koutná Kostínková and Čermák. From foreign publications, we can recommend a clear text by Smith, Flowers and Larkin. For the treatment of the text itself, it is appropriate to move within a hermeneutic circle where the meaning of the individual things appears, is reflected upon and formed in the meaning of the whole, and vice versa. Thus, it is necessary to switch between the specific and the whole (whether it is a word in a sentence, a sequence of conversations, or the whole). ${ }^{64}$

For IPA / ET, it is necessary to emphasise that in Step 0 the self-reflection must include both social scientific knowledge and experience, as well as theological knowledge and experience. Similarly, in the interpretive part of the analytical process (when we consciously assume that we have already realised some insight into the view and meaning attributed by the participants) it is necessary to follow the interpretation not only at the level of social science but also at the level of theological approach to the world. In essence, there are two interpretive phases: a) social science and b) theological. Even at this level (i.e., the level of a particular person), in our opinion, it is necessary to try to achieve the critical mutual correlation within IPA / ET - one view brings critical questions to the view of another, that is, the social science interpretation brings critical questions to the theological interpretation, and vice versa. Within the

63 Ibid., pp. 79-80.

64 KOUTNÁ KOSTÍNKOVÁ and ČERMÁK, Interpretativní... pp. 16-22; Edward NOON, Interpretative Phenomenological Analysis: An Appropriate Methodology for Educational Research?, Journal of Perspecitves in Applied Academic Practice 1/2018, pp. 75-83; SMITH, FLOWERS and LARKIN, Interpretative... pp. 79-107. 
framework of such a focused text (i.e., the use of IPA / ET for empirical theology), we assume that the researcher's knowledge of the theology will be greater than the knowledge of the social sciences (with regard to his primary field of research). However, the opposite situation can be assumed. After all, even within IPA, an increase in the quality of research is accepted through the triangulation of researchers where more researchers participate in the analysis of data. It might be interesting if one of the researchers builds primarily on theology and the other on the social science worldview. This step could also support the abovementioned critical cross-correlation.

After the analysis of the first interview, the same procedure is applied for subsequent interviews. The last analytical step should then be the search for topics, connections, similarities, and contradictions between all realised, rewritten, and analysed interviews, both at the level of social science view (in terms of interpretation) and at the theological level. At an analytical level, this last step offers the possibility to move from a specific one (because the data is presented in individual interviews) to a more general and more theoretical one. ${ }^{65}$ We assume that in this last step it is appropriate within IPA / ET to reflect the emerging topics (participants' view) more generally, to focus on the interpretation of topics through a social science prism, the interpretation of topics from a theological point of view, and their mutual critical discussion (or in other words the mutual critical correlation).

\section{Short Critical Reflection}

The above text is understood as the initial variant of IPA / ET. However, there are some pitfalls that need to be pointed out. Above all, there was no space in the text for a deeper discussion about the impact of different conceptual definitions of terms in the social and theological sciences and the impact of this difference not only on the possibility of connecting or integrating both worldviews, ${ }^{66}$ but also on the course of research itself. The scope of the text does not allow the individual steps to be illustrated with practical, hypothetically formulated examples or procedures. However, there is a freely available text by Koutná Kostínková and Čermák where it is possible to find practical examples of IPA. We also consider it important to emphasise that this is a proposal, that is, it has not yet been directly tested in the research. This step is currently being worked on, though.

\section{Conclusion}

In the text, we present IPA / ET which we understand as a possible modification of interpretive phenomenological analysis for the purposes of research within empirical theology. Within the proposed modification of IPA / ET, we basically copy the procedure of IPA, both in terms of the focus of research and in terms of the selection of communication partners, and also in terms of the analysis process. The difference of IPA / ET lies in the integration of the theological perspective into the whole process - that is, by offering procedures that attach the same validity to theological and social sciences interpretations.

65 KOUTNÁ KOSTÍNKOVÁ and ČERMÁK, Interpretativní..., pp. 16-22, SMITH, FLOWERS and LARKIN, Interpretative...pp. 79-107; SMITH and OSBORN, Interpretative... pp. 66-75.

66 Paul ALLEN, Upholding the Humanum: Science and Theology's Foundational Character, The Heythrop Journal 47/2006, pp. 367-386. 


\section{Contact}

\section{Dr. Jan Kaňák}

Charles University

Hussite Theological Faculty

Department of Historical Theology and Church History

Pacovská 4, 14001 Praha 4

honza.k@mail.muni.cz

\section{Barbora Racková MA}

Charles University

Hussite Theological Faculty

Department of Psychosocial Sciences and Ethics

Pacovská 4, 14001 Praha 4

Barbora.Rackova@htf.cuni.cz 